\title{
LENGTH-WEIGHT AND LENGTH-LENGTH RELATIONSHIPS OF SEVEN LOACH SPECIES (TELEOSTEI: CYPRINIFORMES) FROM FIVE LOCALITIES IN NORTHERN WESTERN GHATS, INDIA
}

\section{Ashwini Keskar ${ }^{1}$, Pradeep Kumkar ${ }^{2}$, Mandar S. Paingankar ${ }^{3}$, Anand Padhye $^{4} \&$ Neelesh Dahanukar ${ }^{5}$}

${ }^{1,5}$ Indian Institute of Science Education and Research, G1 Block, Dr. Homi Bhabha Road, Pashan, Pune, Maharashtra 411008, India

${ }^{1}$ Department of Biodiversity, M.E.S. Abasaheb Garware College, Karve Road, Pune, Maharashtra 411004, India

${ }^{2}$ Department of Zoology, Modern College of Arts, Science and Commerce, Ganeshkhind, Pune, Maharashtra 411007, India

${ }^{3}$ Government Science College, Chamorshi Road, Gadchiroli, Maharashtra-442605, India

${ }^{3,5}$ Systematics, Ecology and Conservation Laboratory, Zoo Outreach Organization, 96 Kumudham Nagar, Villankurichi Road, Coimbatore, Tamil Nadu 641035, India

${ }^{4}$ Department of Zoology, M.E.S. Abasaheb Garware College, Karve Road, Pune, Maharashtra 411004, India

${ }^{1}$ ashwinik@iiserpune.ac.in, ${ }^{2}$ kumkarpradeep@gmail.com, ${ }^{3}$ mandarpaingankar@gmail.com, ${ }^{4}$ adpadhye@gmail.com,

${ }^{5}$ n.dahanukar@iiserpune.ac.in (corresponding author)

Abstract: Length-weight (LWR) and length-length (LLR) relationships of seven loach species (Teleostei: Cypriniformes): Botia striata, Lepidocephalichthys thermalis, Paracanthocobitis mooreh, Indoreonectes evezardi, Nemacheilus anguilla, Nemachilichthys rueppelli and Schistura denisoni were studied from five localities within the Krishna River system of the Indian Western Ghats: Lonawala (Indrayani River), Paud (Mula River), Warje (Mutha River), Bhor (Nira River) and Patan (Koyna River). With the exception of $L$. thermalis all species are endemic to peninsular India, and to our knowledge this is the first presentation of LWR and LLR data for them. New maximum lengths are also reported for I. evezardi, N. anguilla, N. rueppelli and S. denisoni.

Keywords: Allometry, Botiidae, Cobitidae, freshwater fish, Nemacheilidae.
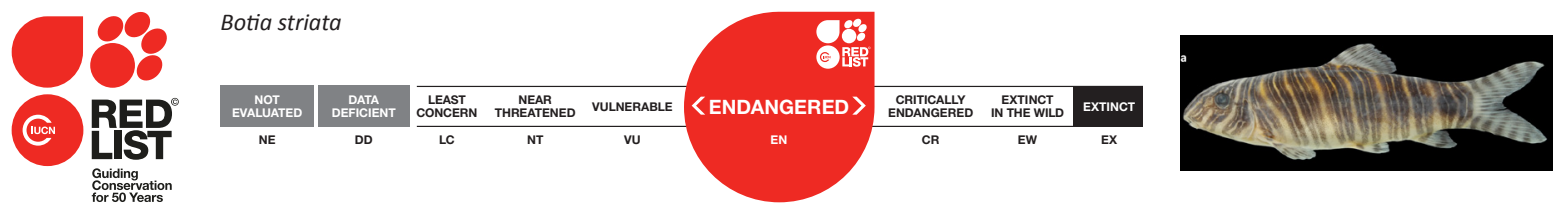

DOI: http://dx.doi.org/10.11609/jott.2462.7.15.8025-8220

Editor: Davor Zanella, Department of Zoology, University of Zagreb, Croatia.

Date of publication: 26 December 2015 (online \& print)

Manuscript details: Ms \# 03916 | Received 16 January 2014 | Final received 03 December 2015 | Finally accepted 07 December 2015

Citation: Keskar, A., P. Kumkar, M.S. Paingankar, A. Padhye \& N. Dahanukar (2015). Length-weight and length-length relationships of seven loach species (Teleostei: Cypriniformes) from five localities in northern Western Ghats, India. Journal of Threatened Taxa 7(15): 8205-8220; http://dx.doi.org/10.11609/jott.2462.7.15.8025-8220

Copyright: @ Keskar et al. 2015. Creative Commons Attribution 4.0 International License. JoTT allows unrestricted use of this article in any medium, reproduction and distribution by providing adequate credit to the authors and the source of publication.

Funding: The study was supported by INSPIRE Faculty Fellowship [IFA12-LSBM-21], Department of Science and Technology, India to Neelesh Dahanukar.

Conflict of Interest: Declared none. The funding agency had no role in study design, results interpretations or manuscript writing.

Author Details: ASHWINI KESKAR is working on diversity, distribution, ecology and evolution of hill stream loaches of the Western Ghats, India. PRADEEP KUMKAR is working on diversity, distribution, ecology and evolution of freshwater fishes. MANDAR S. PAINGANKAR is a molecular biologist and works on vector biology with an emphasis on host parasite interactions. He works on molecular phylogeny and systematics of freshwater fishes as a hobby. ANAND D. PADHYE is an Associate Professor of Zoology. He works on systematics, ecology, diversity, distribution and evolution of amphibians and fishes. NEELESH DAHANUKAR works in ecology and evolution with an emphasis on mathematical and statistical analysis. He is also interested in taxonomy, distribution patterns and molecular phylogeny of freshwater fishes.

Author Contribution: AK, AP and ND designed the study. AK, PK, MSP and ND collected specimens. AK and PK took the measurements. AK and ND performed statistical analysis. AK, AP and ND wrote the manuscript.

Acknowledgements: We are grateful to the Principal, Abasaheb Garware College, and Head, Biodiversity Department, Abasaheb Garware College, and Indian Institute of Science Education and Research, Pune, for providing infrastructural facilities. We are also thankful to an anonymous reviewer for critical comments on the earlier draft of the manuscript. 


\section{INTRODUCTION}

Loaches are hill stream freshwater fish within the order Cypriniformes. The Western Ghats are home to 44 known species from 13 genera from the families Botiidae, Cobitidae, Balitoridae and Nemacheilidae; of these, 18 species are currently threatened with extinction (Dahanukar et al. 2011; Dahanukar \& Raghavan 2013). New loach species have recently been described (Kurup \& Radhakrishnan 2011; Britz et al. 2012; Bhoite et al. 2012; Raghavan et al. 2013b), indicating that our knowledge of their diversity is incomplete, as is information on the ecology and biology of known species (Dahanukar et al. 2011), and of freshwater fish in the Western Ghats in general. This study focused on seven species: Botia striata Rao, 1920, Lepidocephalichthys thermalis (Valenciennes, 1846), Paracanthocobitis mooreh (Sykes, 1839), Indoreonectes evezardi (Day, 1872), Nemacheilus anguilla Annandale, 1919, Nemachilichthys rueppelli (Sykes, 1839) and Schistura denisoni (Day, 1867) (Image 1).

Loaches are adapted to fast-flowing streams, where they cling to small pebbles, rocks, gravel and boulders (Raj 1916; Keskar et al. 2014) and feed on algae, zooplankton and benthic matter (Bhimachar 1935; Keskar et al. 2014). P. mooreh breeds twice a year during August-September and February-March (Kharat et al. 2008), while it has been suggested that $L$. thermalis has a prolonged breeding period from June to November during which it may spawn twice (Kumari \& Nair 1978b). Apart from information on the length weight relationship on $P$. mooreh and $L$. thermalis from two localities, there is virtually no information on the length-weight and length-length relationships, feeding behaviour, breeding behaviour and overall ecology of loaches of the Western Ghats.

Information on allometry, the study of relationship between body size and shape, is essential to understand the basic growth pattern of a species. Allometric patterns in the length-weight relationship (LWR) and length-length relationship (LLR) of fish can provide information on their pattern of growth and ecology (Froese 2006; Kharat et al. 2008; Ali et al. 2013), thus assessing these relationships is an important tool in understanding the growth and condition of fish species (Froese 2006; Golzarianpour et al. 2011; Hossain et al. 2012; Khan \& Sabah 2013).

Allometric relations are depicted by a power law relationship $Y=a X^{b}$ where $X$ and $Y$ are variables, $a$ is the normalization constant and $b$ is the scaling exponent. The mass of a fish is directly proportional to its volume,

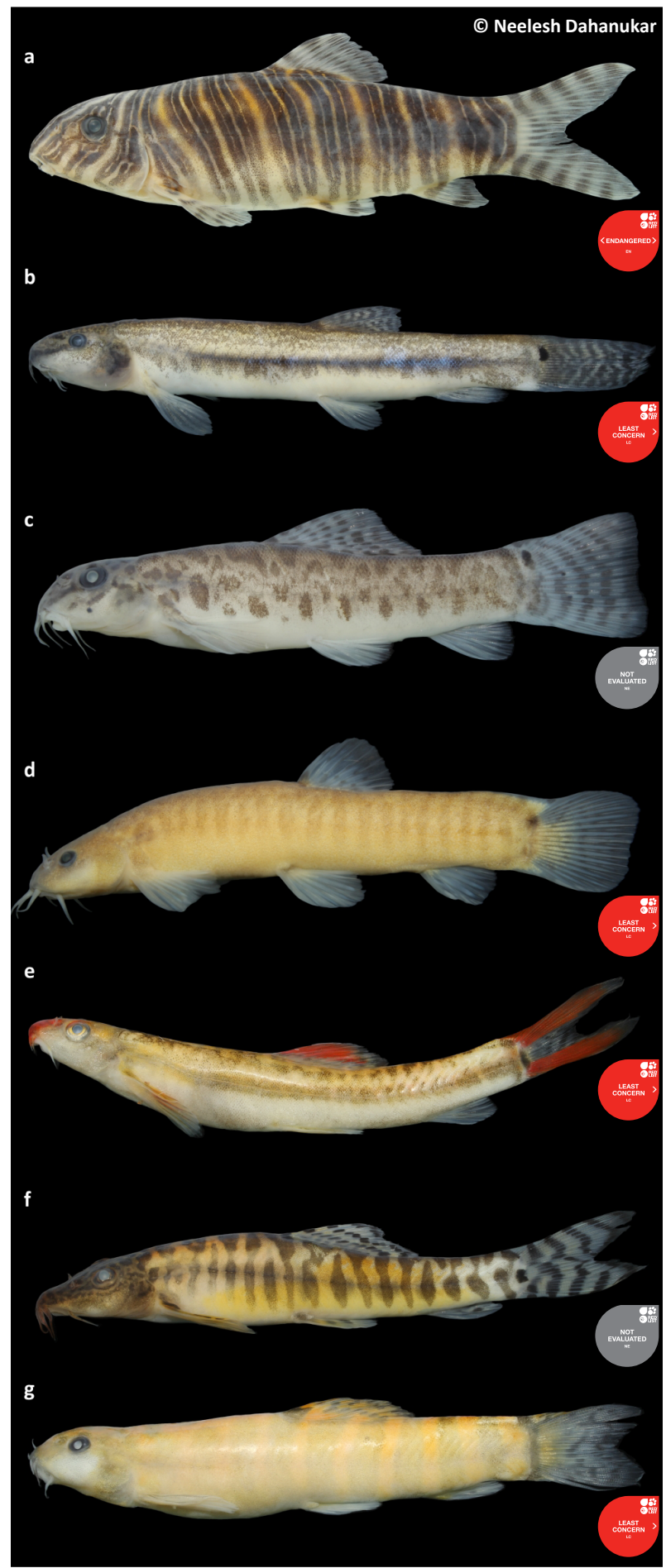

Image 1. Loach species considered in the study.

a - Botia striata, b - Lepidocephalichthys thermalis,

c - Paracanthocobitis mooreh, d - Indoreonectes evezardi,

e - Nemacheilus anguilla, f - Nemachilichthys rueppelli,

g - Schistura denisoni. 
which is proportionate to the cube of its length (i.e., $b=$ 3 ), while the standard length of a fish is directly related to its total length (i.e., $b=1$; Froese 2006; Kharat et al. 2008). If the observed value of the exponent $b$ is as per the expected value we can conclude that the fish grows isometrically, while if the observed value of $b$ is more (i.e. a positive allometric relationship) or less (i.e., a negative allometric relationship), the fish grows nonisometrically. When the growth pattern is non-isometric, one has to explain what factors could determine such growth patterns, which in turn could shed light on the biology and ecology of the fish.

\section{MATERIAL AND METHODS}

\section{Sample collection}

Fresh samples were collected from July 2010 to June 2015 from local fish markets along five rivers in northern Western Ghats (Fig. 1; Table 1). Collection dates for each species spanned the entire year, but sampling was subject to the availability of species in a given locality. The fishing method employed in this area for catching loaches involves a dragnet of very fine mesh size hence there is no bias for particular fish size. No fish were collected intentionally for the current study. All collections adhered to IUCN guidelines for study of threatened species (IUCN 2008). A total of 1872 specimens belonging to three families, seven genera
Table 1. Investigated locations

\begin{tabular}{|l|l|c|c|c|}
\hline Location & River & $\begin{array}{c}\text { Latitude } \\
\left({ }^{(} \mathbf{N}\right)\end{array}$ & $\begin{array}{c}\text { Longitude } \\
\left({ }^{\circ} \mathrm{E}\right)\end{array}$ & $\begin{array}{c}\text { Altitude (m } \\
\text { ASL) }\end{array}$ \\
\hline Lonawala & Indrayani & 18.750 & 73.418 & 621 \\
\hline Bhor & Nira & 18.153 & 73.844 & 572 \\
\hline Paud & Mula & 18.529 & 73.611 & 599 \\
\hline Warje & Mutha & 18.472 & 73.807 & 553 \\
\hline Patan & Koyna & 17.385 & 73.900 & 575 \\
\hline
\end{tabular}

and seven species were collected. Fish were preserved in $10 \%$ formalin.

\section{Data collection}

No studies are available on the length at maturity for the studied species, so we included all specimens $>15 \mathrm{~mm}$ for analysis. Standard length $\left(\mathrm{S}_{\mathrm{L}}\right)$ from the tip of the snout to end of the caudal peduncle, and total length $\left(T_{L}\right)$ from the tip of the snout to the end of caudal fin, was measured for each specimen to the nearest 0.01 $\mathrm{mm}$ using a digital vernier caliper (Mitutoyo, Japan). Weight (W) was measured to the closest $0.01 \mathrm{~g}$.

\section{Statistical analysis}

The LWR was determined using the allometric equation $\mathrm{W}=a \mathrm{~S}_{\mathrm{L}}^{\mathrm{b}}$ (Pauly 1984) and logarithmically transformed into $\log (\mathrm{W})=\log (a)+b \log \left(\mathrm{S}_{1}\right)$. The values of $a$ and $b$ were estimated by least square regression
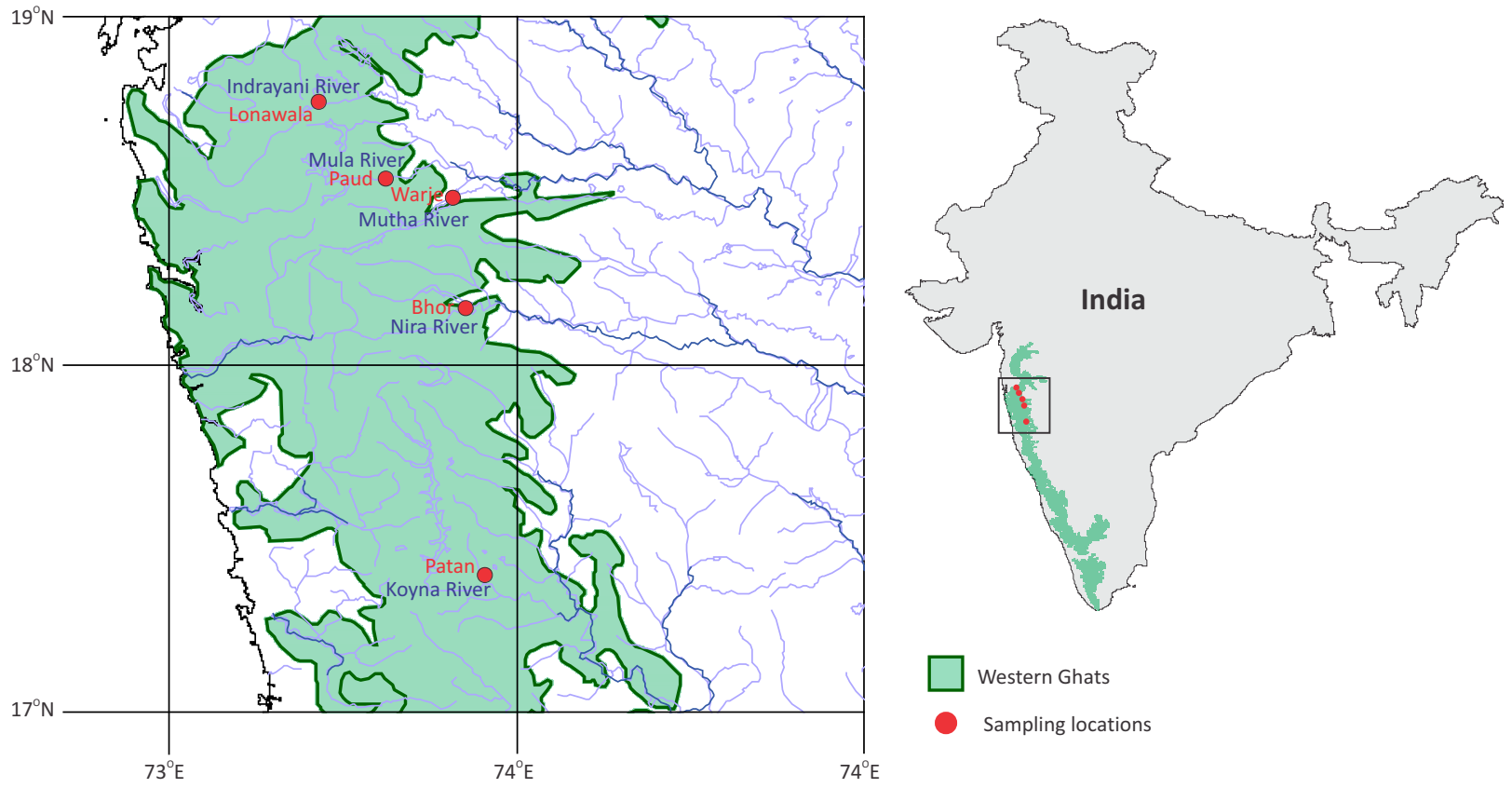

Figure 1. Study sites from Western Ghats of Maharashtra. 
(Zar 1999). Goodness of fit was determined using the coefficient of determination $\left(R^{2}\right)$. The null hypothesis that $b=3$ was tested using two tailed $t$ test as described by Zar (1999). The LLR was estimated as $T_{L}=a S_{L}{ }^{b}$ and its $\log$-log form $\log \left(T_{L}\right)=\log (a)+b \log \left(S_{L}\right)$. Goodness of fit was determined using the coefficient of determination $\left(R^{2}\right)$ and the null hypothesis that $b=1$ was tested using two tailed $t$ test.

\section{RESULTS}

Sample size, minimum and maximum $T_{L}$ and $S_{L}$ and weights of seven loach species from different localities are provided in Table 2. Parameters for LWR and related statistics are provided in Table 3. Parameters for LLR and related statistics are provided in Table 4. Comparison of $b$ values for LWR and LLR across different species and locations are provided in Fig. 2. Scatter plots for all the LWR and LLR relationships are provided in Appendices A-G.

\section{Botia striata}

Botia striata was collected only from Koyna River. The maximum $S_{L}$ of $B$. striata in our collection was $84.84 \mathrm{~mm}$; the maximum reported value is $95 \mathrm{~mm}$ (Talwar \& Jhingran 1991) without providing the locality. The $b$ value of LWR of $B$. striata (Table 3 ) was significantly more than the cubic value expected by isometry $(t=6.263, \mathrm{df}$ $=84, \mathrm{P}<0.0001$ ). The $b$ value of LLR of $B$. striata (Table 4) was significantly lower than 1 , expected by isometric relationship $(t=3.46, d f=84, P=0.001)$.

Table 2. Sample size $(n)$ along with minimum $(\min )$ and maximum $(\max )$ values for standard length $\left(S_{L}\right)$, total length $\left(T_{L}\right)$ and weight $(W)$ for seven loach species from five rivers.

\begin{tabular}{|c|c|c|c|c|c|c|c|c|c|}
\hline \multirow{2}{*}{ Family } & \multirow{2}{*}{ Species } & \multirow{2}{*}{ River } & \multirow{2}{*}{$\mathrm{n}$} & \multicolumn{2}{|c|}{$\mathrm{S}_{\mathrm{L}}(\mathrm{mm})$} & \multicolumn{2}{|c|}{$T_{L}(\mathrm{~mm})$} & \multicolumn{2}{|c|}{ W (g) } \\
\hline & & & & Min & Max & Min & Max & Min & Max \\
\hline Botiidae & Botia striata & Koyna & 85 & 36.60 & 84.84 & 44.10 & 104.71 & 0.94 & 17.03 \\
\hline \multirow{5}{*}{ Cobitidae } & \multirow{5}{*}{$\begin{array}{l}\text { Lepidocephalichthys } \\
\text { thermalis }\end{array}$} & Indrayani & 101 & 25.70 & 58.86 & 29.90 & 67.80 & 0.17 & 2.70 \\
\hline & & Mula & 45 & 24.70 & 40.02 & 27.34 & 46.64 & 0.13 & 0.93 \\
\hline & & Mutha & 89 & 27.72 & 52.69 & 31.44 & 61.70 & 0.21 & 2.01 \\
\hline & & Nira & 54 & 25.66 & 43.88 & 30.21 & 52.91 & 0.16 & 1.17 \\
\hline & & Koyna & 99 & 27.18 & 43.59 & 31.42 & 52.00 & 0.18 & 1.15 \\
\hline \multirow{19}{*}{ Nemacheilidae } & \multirow{4}{*}{$\begin{array}{l}\text { Paracanthocobitis } \\
\text { mooreh }\end{array}$} & Indrayani & 59 & 16.04 & 46.10 & 19.19 & 54.60 & 0.07 & 1.87 \\
\hline & & Mula & 92 & 23.95 & 42.59 & 28.52 & 51.55 & 0.20 & 1.60 \\
\hline & & Nira & 100 & 20.67 & 54.15 & 23.16 & 66.09 & 0.11 & 3.44 \\
\hline & & Koyna & 50 & 25.76 & 59.54 & 30.43 & 71.90 & 0.28 & 4.81 \\
\hline & \multirow{5}{*}{$\begin{array}{l}\text { Indoreonectes } \\
\text { evezardi }\end{array}$} & Indrayani & 16 & 22.95 & 34.99 & 27.93 & 42.42 & 0.26 & 0.80 \\
\hline & & Mula & 50 & 22.14 & 44.21 & 26.26 & 52.35 & 0.17 & 1.73 \\
\hline & & Mutha & 239 & 28.00 & 49.80 & 31.90 & 57.40 & 0.36 & 2.49 \\
\hline & & Nira & 184 & 18.06 & 43.75 & 21.21 & 51.34 & 0.10 & 1.49 \\
\hline & & Koyna & 16 & 25.13 & 32.07 & 30.07 & 38.93 & 0.18 & 0.54 \\
\hline & \multirow{3}{*}{ Nemacheilus anguilla } & Mutha & 74 & 25.70 & 54.20 & 28.90 & 66.40 & 0.18 & 1.73 \\
\hline & & Nira & 111 & 22.55 & 51.53 & 28.01 & 63.43 & 0.12 & 1.47 \\
\hline & & Koyna & 57 & 35.13 & 54.16 & 42.28 & 65.62 & 0.57 & 2.09 \\
\hline & \multirow{3}{*}{$\begin{array}{l}\text { Nemachilichthys } \\
\text { rueppelli }\end{array}$} & Mutha & 51 & 47.90 & 82.10 & 57.50 & 101.30 & 1.32 & 8.20 \\
\hline & & Nira & 24 & 36.31 & 72.20 & 43.77 & 87.30 & 0.55 & 4.98 \\
\hline & & Patan & 50 & 50.84 & 78.37 & 61.82 & 95.37 & 1.32 & 7.00 \\
\hline & \multirow{4}{*}{ Schistura denisoni } & Mula & 33 & 20.11 & 48.72 & 23.21 & 55.83 & 0.12 & 1.57 \\
\hline & & Mutha & 67 & 22.80 & 60.40 & 25.00 & 71.00 & 0.15 & 3.43 \\
\hline & & Nira & 72 & 19.79 & 59.35 & 23.34 & 72.10 & 0.12 & 3.28 \\
\hline & & Koyna & 54 & 17.40 & 54.96 & 22.23 & 63.60 & 0.06 & 2.43 \\
\hline
\end{tabular}




\section{Lepidocephalichthys thermalis}

The maximum $\mathrm{S}$ of $L$. thermalis in our collection was $58.86 \mathrm{~mm}$ from Indrayani River (Table 2), however the known maximum length has been reported up to $80 \mathrm{~mm}$ (Talwar \& Jhingran 1991) without providing the locality. The $b$ value of LWR from four populations (Table 3 ) was significantly higher than the cubic value expected by isometry (Indrayani River: $\mathrm{t}=7.02, \mathrm{df}=100, \mathrm{P}<0.0001$; Mula River: $\mathrm{t}=4.77, \mathrm{df}=44, \mathrm{P}<0.0001$; Mutha River: $\mathrm{t}$ $=3.86, \mathrm{df}=88, \mathrm{P}=0.0002$; Koyna River: $\mathrm{t}=6.17, \mathrm{df}=98$, $\mathrm{P}<0.0001)$. Only in case of Nira River the $b$ value was not significantly different from the cubic value $(t=1.53$, $\mathrm{df}=53, \mathrm{P}=0.132$ ).

The $b$ value of LLR of $L$. thermalis (Table 4 ) was not significantly different from expected value of unity based on isometry for four populations (Mula River: $\mathrm{t}=$ 1.02, $\mathrm{df}=88, \mathrm{P}=0.31$; Mutha River: $\mathrm{t}=0.96, \mathrm{df}=44, \mathrm{P}=$ 0.34; Nira River: $t=0.39, d f=53, P=0.70$; Koyna River: $t$ $=1.79, \mathrm{df}=98, \mathrm{P}=0.08$ ), while it was less than unity only in case of Indrayani River ( $t=3.39, d f=100, P=0.001)$.

\section{Paracanthocobitis mooreh}

The maximum $S_{L}$ of $P$. mooreh from our collection is $59.54 \mathrm{~mm}$ from Koyna River (Table 2), however the maximum length reported is $60 \mathrm{~mm}$ from Mutha River at Warje (Kharat \& Dahanukar 2013). The $b$ value of LWR from three populations (Table 3 ) was significantly higher than cubic value as expected by isometry (Mula River: $t=$ 5.81, $d f=91, P<0.0001$; Nira River: $t=7.06, d f=99, P<$ 0.0001 ; Koyna River: $\mathrm{t}=7.64, \mathrm{df}=49, \mathrm{P}<0.0001$ ). Only in case of Indrayani River the $b$ value was not significantly different from the cubic value $(t=1.59, d f=58, P=0.12$ ). The $b$ value of LLR of $P$. mooreh (Table 4) was not significantly different from isometry for three populations (Mula River: $\mathrm{t}=0.735, \mathrm{df}=91, \mathrm{P}=0.46$; Nira River: $\mathrm{t}=0.96, \mathrm{df}=99, \mathrm{P}=0.34$; Indrayani River $: \mathrm{t}=0.65$, $\mathrm{df}=58, \mathrm{P}=0.52$ ), while it was more than unity in case of Koyna River ( $t=2.38, d f=49, P=0.0213$ ), however this value was not significant when Bonferroni correction was applied to the significance test.

\section{Indoreonectes evezardi}

The maximum $S_{L}$ of $I$. evezardii from our collection is $49.80 \mathrm{~mm}$ from Mutha River (Table 2); the maximum length reported is $38 \mathrm{~mm}$ from Mula-Mutha River of Pune (Menon 1987). The $b$ value of LWR from all five
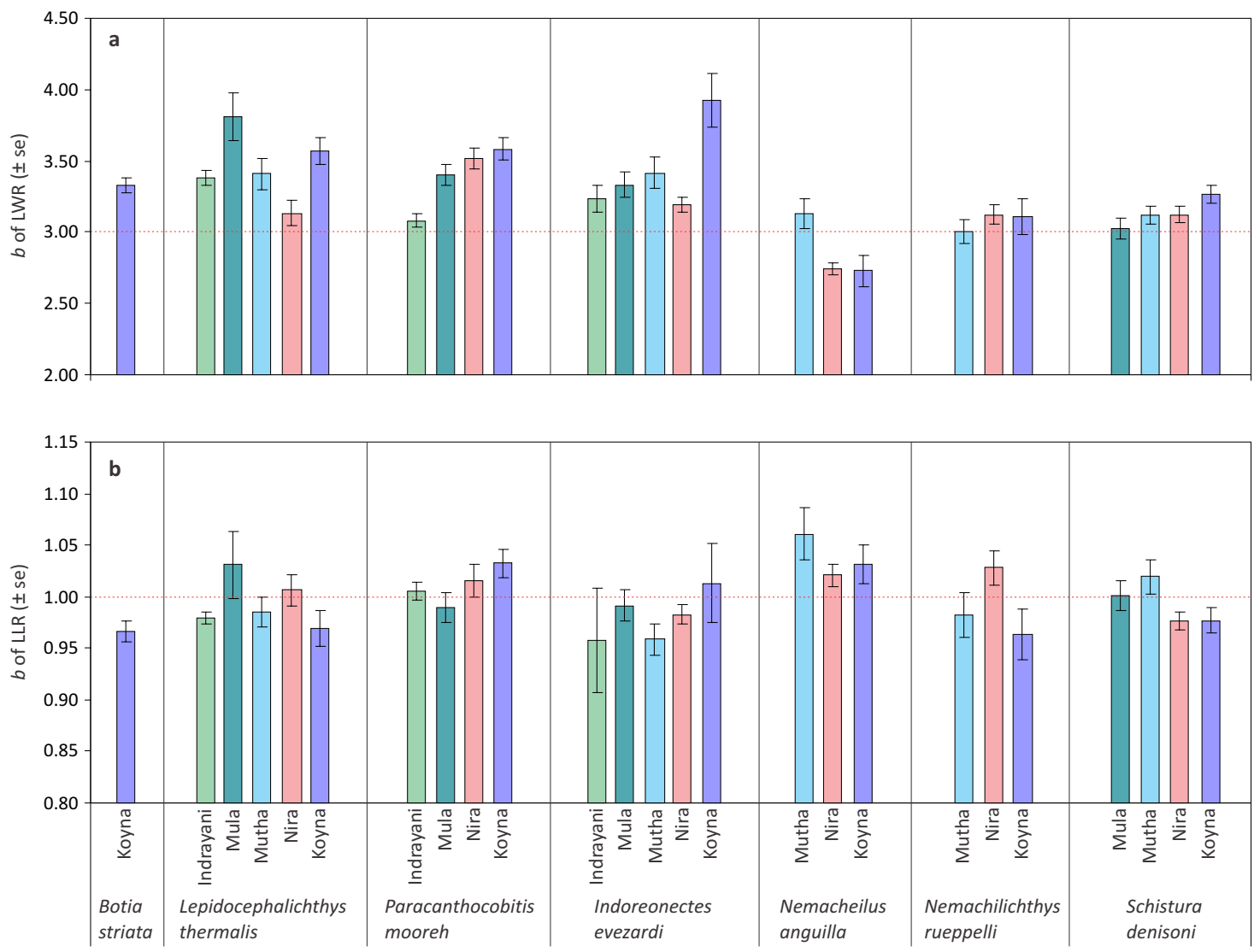

Figure 2. Species and river wise variation in the $b$ value of (a) LWR and (b) LLR. Red dashed lines are expected values from isometric growth. 
Table 3. Length-weight relationship for seven loach species from five rivers.

\begin{tabular}{|c|c|c|c|c|c|}
\hline Species & Location & a & b & se(b) & $\mathbf{R}^{2}$ \\
\hline Botia striata & Koyna & 0.000006 & 3.33 & 0.05 & 0.98 \\
\hline \multirow{5}{*}{$\begin{array}{l}\text { Lepidocephalichthys } \\
\text { thermalis }\end{array}$} & Indrayani & 0.000003 & 3.38 & 0.05 & 0.98 \\
\hline & Mula & 0.000001 & 3.81 & 0.17 & 0.92 \\
\hline & Mutha & 0.000003 & 3.41 & 0.11 & 0.92 \\
\hline & Nira & 0.000008 & 3.13 & 0.09 & 0.96 \\
\hline & Koyna & 0.000002 & 3.57 & 0.09 & 0.94 \\
\hline \multirow{4}{*}{$\begin{array}{l}\text { Paracanthocobitis } \\
\text { mooreh }\end{array}$} & Indrayani & 0.000010 & 3.08 & 0.05 & 0.98 \\
\hline & Mula & 0.000004 & 3.40 & 0.07 & 0.96 \\
\hline & Nira & 0.000003 & 3.52 & 0.07 & 0.96 \\
\hline & Koyna & 0.000002 & 3.58 & 0.08 & 0.98 \\
\hline \multirow{5}{*}{$\begin{array}{l}\text { Indoreonectes } \\
\text { evezardi }\end{array}$} & Indrayani & 0.000008 & 3.24 & 0.09 & 0.99 \\
\hline & Mula & 0.000005 & 3.33 & 0.09 & 0.97 \\
\hline & Mutha & 0.000004 & 3.42 & 0.11 & 0.92 \\
\hline & Nira & 0.000009 & 3.19 & 0.06 & 0.95 \\
\hline & Koyna & 0.000001 & 3.92 & 0.19 & 0.97 \\
\hline \multirow{3}{*}{$\begin{array}{l}\text { Nemacheilus } \\
\text { anguilla }\end{array}$} & Mutha & 0.000006 & 3.13 & 0.10 & 0.93 \\
\hline & Nira & 0.000030 & 2.74 & 0.04 & 0.98 \\
\hline & Koyna & 0.000035 & 2.73 & 0.11 & 0.92 \\
\hline \multirow{3}{*}{$\begin{array}{l}\text { Nemachilichthys } \\
\text { rueppelli }\end{array}$} & Mutha & 0.000011 & 3.00 & 0.08 & 0.96 \\
\hline & Nira & 0.000008 & 3.12 & 0.07 & 0.99 \\
\hline & Patan & 0.000009 & 3.11 & 0.13 & 0.93 \\
\hline \multirow{4}{*}{ Schistura denisoni } & Mula & 0.000010 & 3.02 & 0.08 & 0.98 \\
\hline & Mutha & 0.013000 & 3.12 & 0.06 & 0.98 \\
\hline & Nira & 0.000010 & 3.12 & 0.06 & 0.98 \\
\hline & Koyna & 0.000007 & 3.27 & 0.06 & 0.98 \\
\hline
\end{tabular}

populations (Table 3) was significantly higher than expected by isometry (Indrayani River: $\mathrm{t}=2.57 \mathrm{df}=15$, $\mathrm{P}=0.02$; Mula River: $\mathrm{t}=3.73, \mathrm{df}=49, \mathrm{P}=0.0005$; Mutha River : $\mathrm{t}=3.96, \mathrm{df}=238, \mathrm{P}<0.0001$; Nira River: $\mathrm{t}=3.42$, $\mathrm{df}=183, \mathrm{P}<0.0001 ;$ Koyna River: $\mathrm{t}=4.90, \mathrm{df}=15, \mathrm{P}=$ $0.0002)$. Only in the case of Indrayani River population the $b$ value was not significantly different than cubic value when Bonferroni correction was applied.

The $b$ value of LLR of $I$. evezardii (Table 4) was not significantly different from isometry for four populations except (Indrayani River: $\mathrm{t}=0.84$, df $=15, \mathrm{P}=0.41$; Mula River: $\mathrm{t}=0.54, \mathrm{df}=49, \mathrm{P}=0.59$; Nira River: $\mathrm{t}=1.77, \mathrm{df}$ $=183, \mathrm{P}=0.08$; Koyna River: $\mathrm{t}=0.35, \mathrm{df}=15, \mathrm{P}=0.73$ ), while it was less than unity in case of Mutha River $(\mathrm{t}=$ $2.80, \mathrm{df}=238, \mathrm{P}=0.0055)$, however, this value was not significant when Bonferroni correction was applied to the significance test.
Table 4. Length-length relationship for seven loach species from five rivers.

\begin{tabular}{|c|c|c|c|c|c|}
\hline Species & Location & a & b & se(b) & $\mathbf{R}^{2}$ \\
\hline Botia striata & Koyna & 1.42 & 0.97 & 0.01 & 0.99 \\
\hline \multirow{5}{*}{$\begin{array}{l}\text { Lepidocephalichthys } \\
\text { thermalis }\end{array}$} & Indrayani & 1.26 & 0.98 & 0.01 & 0.99 \\
\hline & Mula & 1.03 & 1.03 & 0.03 & 0.96 \\
\hline & Mutha & 1.24 & 0.98 & 0.01 & 0.98 \\
\hline & Nira & 1.15 & 1.01 & 0.02 & 0.99 \\
\hline & Koyna & 1.32 & 0.97 & 0.02 & 0.97 \\
\hline \multirow{4}{*}{$\begin{array}{l}\text { Paracanthocobitis } \\
\text { mooreh }\end{array}$} & Indrayani & 1.17 & 1.01 & 0.01 & 0.99 \\
\hline & Mula & 1.24 & 0.99 & 0.01 & 0.98 \\
\hline & Nira & 1.14 & 1.02 & 0.02 & 0.98 \\
\hline & Koyna & 1.07 & 1.03 & 0.01 & 0.99 \\
\hline \multirow{5}{*}{$\begin{array}{l}\text { Indoreonectes } \\
\text { evezardi }\end{array}$} & Indrayani & 1.37 & 0.96 & 0.05 & 0.96 \\
\hline & Mula & 1.22 & 0.99 & 0.02 & 0.99 \\
\hline & Mutha & 1.34 & 0.96 & 0.01 & 0.95 \\
\hline & Nira & 1.24 & 0.98 & 0.01 & 0.98 \\
\hline & Koyna & 1.15 & 1.01 & 0.04 & 0.98 \\
\hline \multirow{3}{*}{$\begin{array}{l}\text { Nemacheilus } \\
\text { anguilla }\end{array}$} & Mutha & 0.95 & 1.06 & 0.03 & 0.96 \\
\hline & Nira & 1.13 & 1.02 & 0.01 & 0.99 \\
\hline & Koyna & 1.09 & 1.03 & 0.02 & 0.98 \\
\hline \multirow{3}{*}{$\begin{array}{l}\text { Nemachilichthys } \\
\text { rueppelli }\end{array}$} & Mutha & 1.31 & 0.98 & 0.02 & 0.98 \\
\hline & Nira & 1.09 & 1.03 & 0.02 & 0.99 \\
\hline & Patan & 1.42 & 0.96 & 0.02 & 0.97 \\
\hline \multirow{4}{*}{ Schistura denisoni } & Mula & 1.17 & 1.00 & 0.01 & 0.99 \\
\hline & Mutha & 1.08 & 1.02 & 0.02 & 0.98 \\
\hline & Nira & 1.30 & 0.98 & 0.01 & 0.99 \\
\hline & Koyna & 1.28 & 0.98 & 0.01 & 0.99 \\
\hline
\end{tabular}

\section{Nemacheilus anguilla}

The maximum $S_{L}$ of $N$. anguilla from our collection is $54.20 \mathrm{~mm}$ from Mutha River (Table 2); the maximum length reported is $50 \mathrm{~mm}$ (Menon 1987) without providing the locality. The $b$ value of LWR from two populations (Table 3 ) was significantly less than expected by isometry (Nira River: $t=6.24$, $d f=110, P<0.0001$; Koyna River: $\mathrm{t}=2.44, \mathrm{df}=56, \mathrm{P}=0.02$ ). The significantly low value in Koyna River, however, was not significant after Bonferroni correction was applied. In case of Mutha River the $b$ value was not significantly different than cubic value $(\mathrm{t}=1.27, \mathrm{df}=73, \mathrm{P}=0.21)$.

The $b$ value of LLR of $N$. anguilla (Table 4) was significantly different from sometry for two populations (Mutha River: $\mathrm{t}=2.36$, $\mathrm{df}=73, \mathrm{P}=0.02$; Nira River: $\mathrm{t}$ $=2.00, \mathrm{df}=110, \mathrm{P}=0.0481$ ), however, these values were not significant when Bonferroni correction was applied. In the case of Koyna River the $b$ value was not 

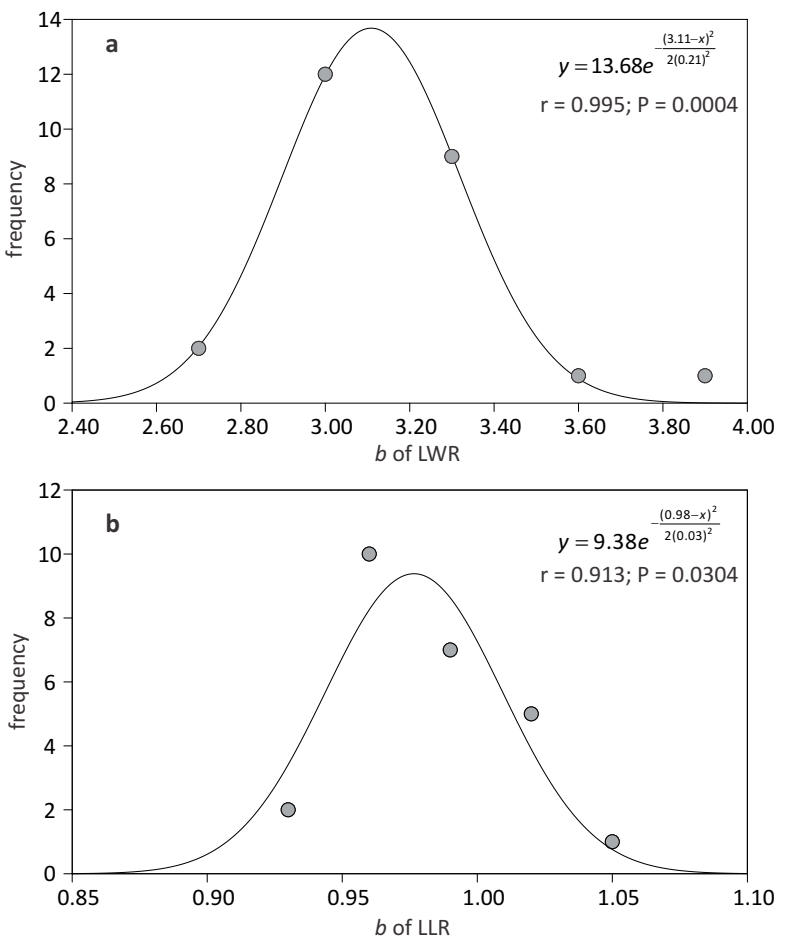

Figure 3. Distribution of $b$ values of (a) LWR and (b) LLR for all the species and from all the Rivers considered in the current study. Both the plots show good fit for the normal distribution.

significantly different from unity. $(t=1.65, d f=56, P=$ 0.11).

\section{Nemachilichthys rueppelli}

The maximum $\mathrm{S}_{1}$ of $N$. rueppelii from our collection is $82.10 \mathrm{~mm}$ from Mutha River (Table 2); the maximum length reported is $74 \mathrm{~mm}$ (Menon 1999) without providing the locality. The $b$ value of LWR from all three populations (Table 3 ) was not significantly different from cubic value as expected by isometry (Mutha River: $t=$ 0.04, $d f=50, P=0.97$; Nira River: $t=1.78, d f=23, P=$ 0.09; Koyna River: $\mathrm{t}=0.87, \mathrm{df}=49, \mathrm{P}=0.39$ ).

The $b$ value of LLR of $N$. rueppelli (Table 4) was not significantly different from expected value of unity based on isometry for all three populations (Mutha River: $t=$ $0.80, d f=50, P=0.43$; Nira River: $t=1.65, d f=23, P=$ 0.11 ; Koyna River: $\mathrm{t}=1.49, \mathrm{df}=49, \mathrm{P}=0.14$ )

\section{Schistura denison}

The maximum $S_{\perp}$ of S.denisoni from our collection is $60.40 \mathrm{~mm}$ from Mutha River (Table 2), the maximum length reported is $51.1 \mathrm{~mm}$ from Bhawani River, Cauvery basin, at Mettupalayam (Menon 1987). The $b$ value of LWR from two populations was not significantly different than cubic value as expected by isometry (Mula River: $t$
$=0.30, \mathrm{df}=32, \mathrm{P}=$ 0.76; Mutha River: $\mathrm{t}=1.90, \mathrm{df}=66$, $P=0.06)$. The $b$ value was significantly different from cubic value for two populations (Nira River: $t=2.16$, $d f=$ 71, $\mathrm{P}=0.03$; Koyna River: $\mathrm{t}=4.41, \mathrm{df}=53, \mathrm{P}<0.0001$ ), however the $b$ value was not significant for Nira River when Bonferroni correction was applied.

The $b$ value of LLR of $S$. denisoni (Table 4) was not significantly different from expected value for isometry for three populations (Mula River $t=0.06, d f=32, P=$ 0.95; Mutha River: $t=1.13, d f=66, P=0.26$; Koyna River: $t=1.91, d f=53, P=0.06$ ). The $b$ value was significantly less than unity in the case of Nira River $(t=2.63, d f=$ $71, P=0.01$ ), however, the significance was lost when Bonferroni correction was applied.

\section{Distribution of $\boldsymbol{b}$ values}

The $b$ values for LWR of the investigated species for all sites ranged between 2.72 to 3.92 (Table 3). There was considerable variation in the LWR $b$ values across species and across sites for the same species (Fig. 2a). The distribution of LWR $b$ values for all the species from all different sites followed a Gaussian curve with a mean of 3.11 and standard deviation 0.21 (Fig. 3a). The mean value of LWR $b$ was significantly larger than cubic value ( $\mathrm{t}=7.99$, $\mathrm{df}=4, \mathrm{P}=0.0013$ ).

The $b$ value of LLR ranged between 0.96 to 1.06 (Table $4)$. There was considerable variation in the $\operatorname{LLR} b$ values across species and across sites for the same species (Fig. $2 b)$. However, the distribution of LLR $b$ values for all the species from all different sites followed a Gaussian curve with a mean of 0.98 and standard deviation 0.03 (Fig. $3 b)$. The mean value of LLR $b$ was significantly lower than unity as expected by isometry $(t=3.08, d f=4, P$ $=0.037)$.

\section{Effects of sample size}

The sample sizes for species collected from different localities varied owing to their availability. Potential sample size bias was checked using two different methods. The $b$ values of LWR and LLR were plotted against the sample size (Figs. $4 a$ and $4 c$ respectively), showing no significant correlation (Figs. 4a and 4c). To understand whether the bias was created regarding deviation from the expected values of $b$ based on isometry, the absolute (or modulus) of deviation of $b$ value from the expected value against the sample size was plotted (Figs. $4 \mathrm{~b}$ and $4 \mathrm{~d}$ ). There was no significant relationship in the absolute deviation and the sample size (Figs. 4b and 4d). 

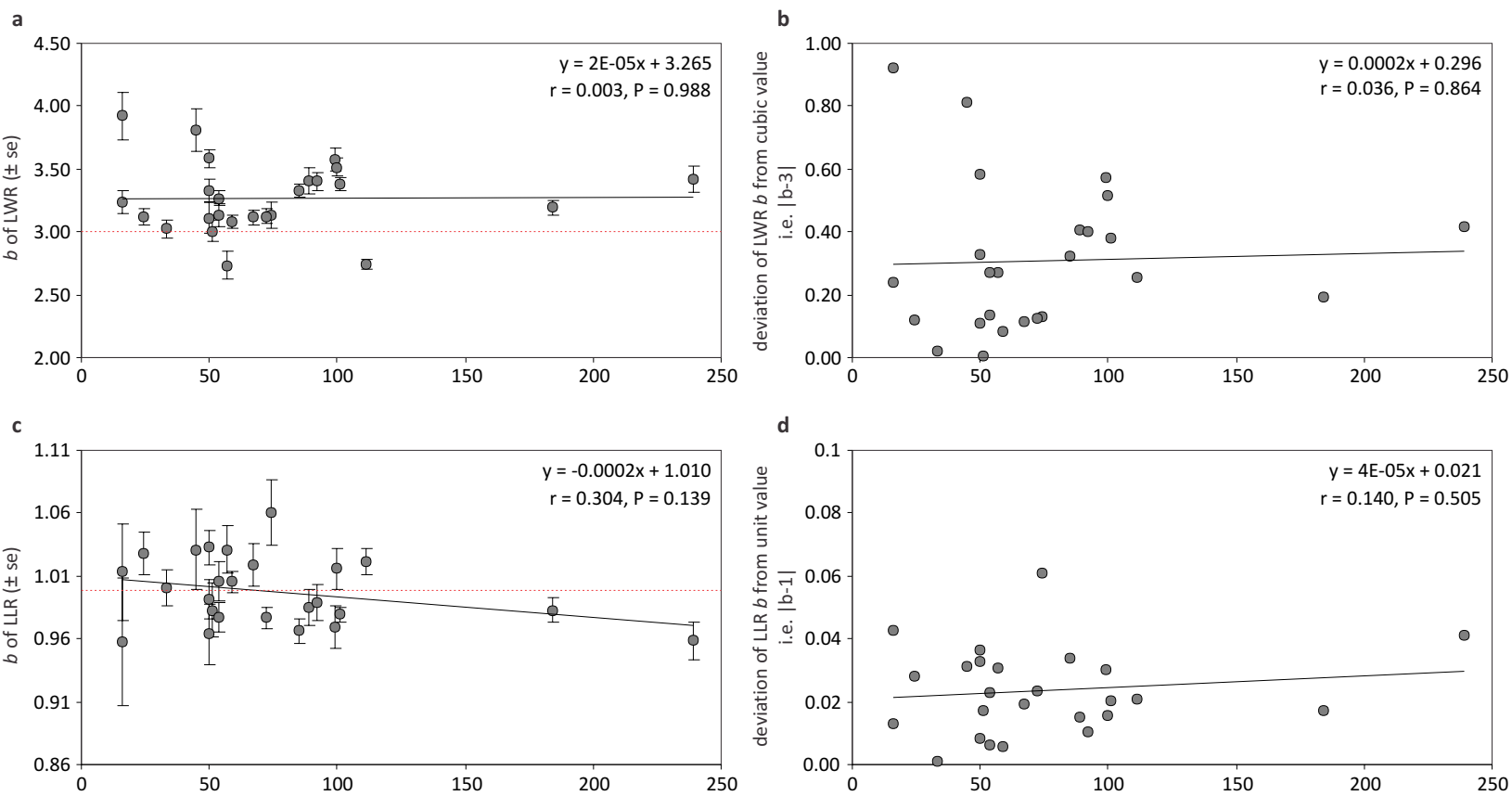

Figure 4. Effect of sample size on (a) $b$ values of the LWR, (b) deviation in the $b$ values of LWR form cubic value expected from isometry, (c) $b$ values of the LLR, (b) deviation in the $b$ values of LLR form unit value expected from isometry. Note that none of the trend lines are significant indicating that the sample size has no effect on the value of $b$ and its deviation from isometry. Red dashed lines in (a) and (c) are expected values from isometric growth.

\section{DISCUSSION}

This study reports new maximum standard lengths for I. evezardii, N. anguilla, N. rueppelli and S. denisoni. While the maximum standard length of $B$. striata is $95 \mathrm{~mm}$ (Talwar \& Jhingran 1991), we have rarely seen this fish to exceed $60 \mathrm{~mm}$. Our observations are unlikely to be biased by sampling methods. Botia striata is under high fishing pressure due to its exploitation for the aquarium trade (Raghavan et al. 2013a) despite being a threatened species (Dahanukar 2011). It is essential that further studies should be done to understand whether fishing of $B$. striata is sustainable, and whether the fishing pressure has any effect on the current report of small size of this fish in the wild.

There are very few studies on the LWR of loaches of the Western Ghats, which to our knowledge are only available for Mesonoemacheilus triangularis (Kumari \& Nair 1978a; Mercy et al. 2008), L. thermalis (Kumari \& Nair 1978a) and P. mooreh (Kharat et al. 2008; Kharat \& Dahanukar 2013). As a result this study provides the first LWR data for B. striata, I. evezardi, N. anguilla, $N$. rueppelli and S. denisoni. LWR values were also provided for $L$. thermalis and $P$. mooreh from new localities. No studies are available on LLR of loaches of the Western Ghats. As a result, this study provides the first data on
LLR values for all seven species

Kumari \& Nair (1978a) reported the LWR $b$ value of $L$. thermalis from Kerala, India to be higher than expected from isometry (3.294 for males and 3.162 for females), however, they suggested that the difference was not significant. In our case the $b$ values of all five populations of $L$. thermalis were higher than three, and in four populations this was significant. It is known that L. thermalis has a prolonged breeding period from June to November during which it may spawn twice (Kumari \& Nair 1978b). Extended breeding periods can skew the LWR relationship depending on the sampling period. However, given that wide range of sizes and well mixed samples from various months were included in the study, it is unlikely that the gender or age or the reproductive stage of the specimens made a significant contribution.

In the case of $P$. mooreh, Kharat et al. (2008) found an LWR $b$ value of 2.56 (SE=0.1214) for a population collected from Mutha River, and they argued that it was significantly less than three. In a more extensive study from Mutha River, Kharat \& Dahanukar (2013) found an LWR $b$ value of 2.81 (SE=0.05) which was significantly less than three. They also showed that the LWR $b$ values for males and females were significantly $<3$ but not significantly different from each other. For the populations investigated in the current study 
we observed LWR $b$ values $>3$. One possibility is that the populations studied in the present case are from relatively less polluted areas as compared to the populations studied by Kharat et al. (2008), and Kharat \& Dahanukar (2013).

The distribution of $b$ values of LWR and LLR followed a normal distribution with a mean significantly different from three and unit values for LWR and LLR respectively (Fig. 3). The mean $b$ value for LWR was significantly larger than expected for isometry, indicating that the increment in the weight is more per unit increment in the length. This indirectly suggests that the loaches in the studied sampling locations are quite healthy. The mean $b$ value for LLR was significantly lesser than unity as expected by isometry, indicating that the increment in the $T_{L}$ is less per unit increment in the $S_{L}$. As the only difference in $T_{L}$ and $S_{L}$ is the length of caudal fin, it can be deduced that increment in the caudal fin is less per unit increment in the $S_{L}$. Ali et al. (2013) found a similar trend for three species of snakehead fishes of the genus Channa. Since the species of Channa and loaches have an elongated body structure, ecological studies that can investigate the effect of shape on the LLR could shed more light on the non-isometric relations in LLR.

A wide variation in the $b$ value of both LWR and LLR across different species as well as populations was observed (Fig. 2). This was especially true for the LWR $b$. The LLR $b$ values, even though they were variable, were not much significantly different from the expected unit value by isometry. It has been suggested that the power $b$ in LWR of fish is influenced by the species, gender, age, season, ontogenic changes, fish feeding, number of specimen examined, length ranges of the specimen caught, anthropogenic stressors and variation in gonad weight during various stages of sexual maturity (Türkmen et al. 2001; Moutopoulos \& Stergiou 2002; Peck et al. 2005; Froese 2006; Kharat et al. 2008; Winfield et al. 2012). Although it is difficult for us to systematically eliminate all of the above-mentioned factors, the recommendations given by Froese (2006) were followed wherever possible. The scatter of points provided in the Appendices A-G suggests that the trend lines, and as a result the $b$ values of LWR and LLR, are not an artifact of outliers in the populations. Further, we have also shown that the deviation in the $b$ values of both LWR and LLR are not influenced by the sample size variation (Figure 4). We could not account for the gender variation. However, at least for two different species, namely, $L$. thermalis and $P$. mooreh, previous studies have shown that the LWR $b$ values do not vary with gender (Kumari \& Nair 1978a; Kharat \& Dahanukar 2013). If this is a general trend of the loaches, gender variation may not contribute to the variations in LWR $b$ values observed in our study. We considered specimens collected from different seasons and from wide size range to minimize the effect of seasonal variation, size variation or reproductive maturity. However, contribution of these factors cannot be completely ruled out and a further systematic study in this respect is essential. A cross location and cross species comparison of $b$ values for LWR and LLR showed no particular trend. Indicating that the habitat at different sampling locations had little effect in determining the allometric relationships.

Very little information is available on the ecology of most of the freshwater fishes, which is hindering conservation efforts in the Western Ghats of India (Dahanukar et al. 2011). This is especially true for the hill stream loaches, which do not have commercial fishery value and are therefore not subject to detailed studies. Baseline data on $S_{L^{\prime}} T_{L^{\prime}}, W$, LWR and LLR for seven loaches from five localities will be useful for comparisons of life history traits and morphological aspects of populations of loaches inhabiting different localities. They can also help in identifying areas better suited for the growth of the species, so as to aid in identifying areas for their conservation. In our case, for example, areas where species showed $b$ values of LWR, which were significantly more than the cube, suggests that the species show more increment in weight per unit increment in length and are therefore healthier. Such locations are potential sites for conservation of these species. A more practical use of the data generated in the study is the availability of LWR relationships, which can enable fish biologists to derive weight estimates for the loaches from studied areas that are measured but not weighed. With new maximum lengths for four species of loaches and LWR and LLR statistics for seven species of loaches from five localities, the results presented in the current study will also be important for filling the data gaps in FishBase (www.fishbase.org/) as per recommendation number 12 in Froese (2006).

\section{REFERENCES}

Ali, A., N. Dahanukar \& R. Raghavan (2013). Length-weight and lengthlength relationship of three species of snakehead fish, Channa diplogramma, $C$. marulius and $C$. striata from the riverine reaches of Lake Vembanad, Kerala, India. Journal of Threatened Taxa 5(13): 4769-4773; http://dx.doi.org/10.11609/JoTT.o3353.4769-73

Bhimachar, B.S. (1935). A study of the correlation between the feeding habits and the structure of the hind brain in the south Indian cyprinoid fishes. Proceedings of the Royal Society, London 117: 258272; http://dx.doi.org/10.1098/rspb.1935.0028

Bhoite, S., S. Jadhav \& N. Dahanukar (2012). Balitora laticauda, a 
new species of stone loach (Teleostei: Cypriniformes: Balitoridae) from Krishna River, northern Western Ghats, India. Journal of Threatened Taxa 4(11): 3038-3049; http://dx.doi.org/10.11609/ JoTT.03129.3038-49

Britz, R., A. Ali \& R. Raghavan (2012). Pangio ammophila, a new species of eel-loach from Karnataka, southern India (Teleostei: Cypriniformes: Cobitidae). Ichthyological Explorations of Freshwaters 23(1): 45-50.

Dahanukar, N. (2011). Botia striata. In: IUCN 2012. IUCN Red List of Threatened Species. Version 2012.2. <www.iucnredlist.org> Downloaded on 09 December 2012; http://dx.doi.org/10.2305/ IUCN.UK.2011-1.RLTS.T168591A6521075.en

Dahanukar, N., R. Raghavan, A. Ali, R. Abraham \& C.P. Shaji (2011). The status and distribution of freshwater fishes of the Western Ghats. Chapter 3, pp. 21-48. In: Molur, S., Smith, K.G., Daniel, B.A. \& Darwall, W.R.T. (compilers). The Status and Distribution of Freshwater Biodiversity in The Western Ghats, India. Cambridge, UK and IUCN, Gland, Switzerland and Zoo Outreach Organisation, Coimbatore, India, 116pp.

Dahanukar, N. \& R. Raghavan (2013). Freshwater fishes of Western Ghats: Checklist v 1.0 August 2013. MIN - Newsletter of FFSG-SA 1 6-16

Froese, R. (1998). Length-weight relationships for 18 less-studied fish species. Journal of Applied Ichthyology 14: 117-118; http://dx.doi. org/10.1111/j.1439-0426.1998.tb00626.x

Froese, R. (2006). Cube law, condition factor and weight-length relationships: history, meta-analysis and recommendations. Journal of Applied Ichthyology 22: 241-253; http://dx.doi.org/10.1111/ j.1439-0426.2006.00805.x

Froese, R., A.C. Tsikliras \& K.I. Stergiou (2011). Editorial note on weight-length relations of fishes. Acta Ichthyologica et Piscatoria 41: 261-263; http://dx.doi.org/10.3750/AIP2011.41.4.01

Golzarianpour, K., A. Abdoli \& B.H. Kiabi (2011). Lengthweight relationships for nine nemacheilian loaches (Teleostei: Nemacheilidae) from Iran. Journal of Applied Ichthyology 27: 14111412; http://dx.doi.org/10.1111/j.1439-0426.2011.01798.x

Hossain, M.Y., M.M. Rahman, B. Fulanda, M.A.S. Jewel, F. Ahamed \& J. Ohtomi (2012). Length-weight and length-length relationships of five threatened fish species from the Jamuna (Brahmaputra River tributary) River, northern Bangladesh. Journal of Applied Ichthyology 28: 275-277; http://dx.doi.org/10.1111/j.1439-0426.2011.01900.x

IUCN (2008). 'IUCN Policy Statement on Research Involving Species at Risk of Extinction'.http://intranet.iucn.org/webfiles/doc/ IUCNPolicy/Resolutions/2008_WCC_4/English/RES/res_4_105 guidelines_regarding_research_and_scientific_collecting_of_ threatened_species.pdf; accessed on 30 December 2011

Keskar, A., A. Padhye \& N. Dahanukar (2014). Fighting against all odds: the struggle for existence among hill stream loaches of northern
Western Ghats. Min - Newsletter of FFSG 2: 25-29.

Khan, M.A. \& Sabah (2013). Length-weight and length-length relationships for five fish species from Kashmir valley. Journal of Applied Ichthyology 29: 283-284; http://dx.doi.org/10.1111/j.14390426.2012.02061.x

Kharat, S.S., Y.K. Khillare \& N. Dahanukar (2008). Allometric scaling in growth and reproduction of a freshwater loach Nemacheilus morreh (Sykes, 1839). Electronic Journal of Ichthyology 4: 8-17.

Kharat, S.S. \& N. Dahanukar (2013). Population dynamics of the Hill Stream Loach Acanthocobitis mooreh (Sykes, 1839) (Cypriniformes: Nemacheilidae) from northern Western Ghats of India. Journal of Threatened Taxa 5(11): 4562-4568; http://dx.doi.org/10.11609/ JoTT.03301.4562-8

Kumari, S.D.R. \& N.B. Nair (1978a). Length-weight relationship of the loaches Noemacheilus triangularis Day and Lepidocephalus thermalis (Cuv. \& Val). Matsya 4: 52-58.

Kumari, S.D.R. \& N.B. Nair (1978b). Maturation and spawning in a tropical loach, Lepidocephalus thermalis (Cuv. \& Val). Proceedings of Indian National Science Academy B 44: 52-58.

Kurup, B.M. \& K.V. Radhakrishnan (2011). Fishes of the genus Homaloptera van Hasselt, 1823 in Kerala, with description of a new species Homaloptera silasi. Journal of the Bombay Natural History Society 107(3): 224-226.

Menon, A.G.K. (1987). The fauna of India and the adjacent countries. Pisces. Vol. IV. Teleostei - Cobitoidea. Part 1. Homalopteridae. Zoological Survey of India.

Menon, A.G.K (1999). Checklist of freshwater fishes of India. Records of Zooogical Survey of India Occasional Paper 175: 1-366.

Mercy T.V.A., E. Jacob \& R.K. Bhaskar (2008) Length-weight relationship of sixteen species of indigenous ornamental fishes of the Western Ghats of India. Indian Journal of Fisheries 55(4): 337-339.

Moutopoulos, D.K. \& K.I. Stergiou (2002). Length-weight and length-length relationships of fish species from the Aegean Sea (Greece). Journal of Applied Ichthyology 18: 200-203; http://dx.doi. org/10.1046/j.1439-0426.2002.00281.x

Pauly, D. (1984). Fish Population Dynamics in Tropical Waters: A Manual for Use with Programmable Calculators. ICLARM. Manila, Philippines, $325 p p$.

Peck, M.A., C. Clemmesen, \& J.P. Herrmann (2005). Ontogenic changes in the allometric scaling of the mass and length relationship in Sprattus sprattus. Journal of Fish Biology 66: 882-887; http:// dx.doi.org/10.1111/j.0022-1112.2005.00651.x

Raghavan, R., N. Dahanukar, M. Tlusty, A. Rhyne, K. Krishnakumar, S. Molur \& A.M. Rosser (2013a). Uncovering an obscure trade: threatened freshwater fishes and the aquarium pet markets. Biological Conservation 164: 158-169; http://dx.doi.org/10.1016/j. biocon.2013.04.019

Raghavan, R., J. Tharian, A. Ali, S. Jadhav \& N. Dahanukar
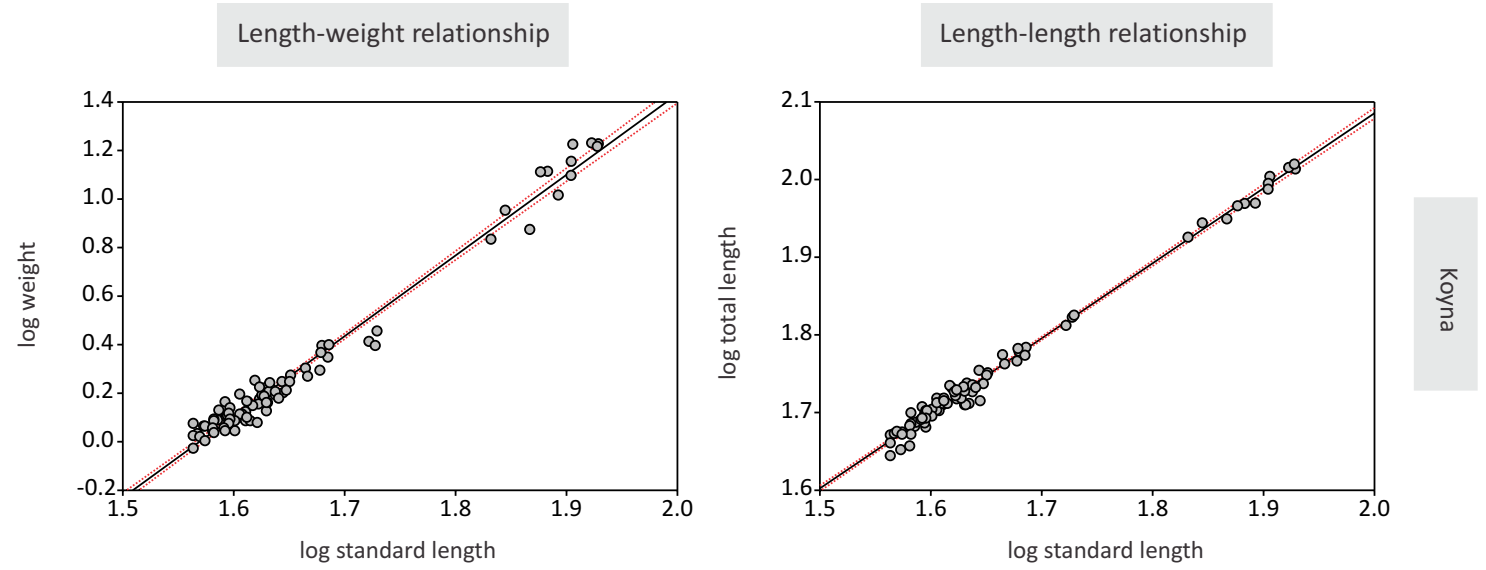

Appendix A. Scatter plots for Botia striata. Dashed lines are $95 \%$ confidence intervals for the regression line. 

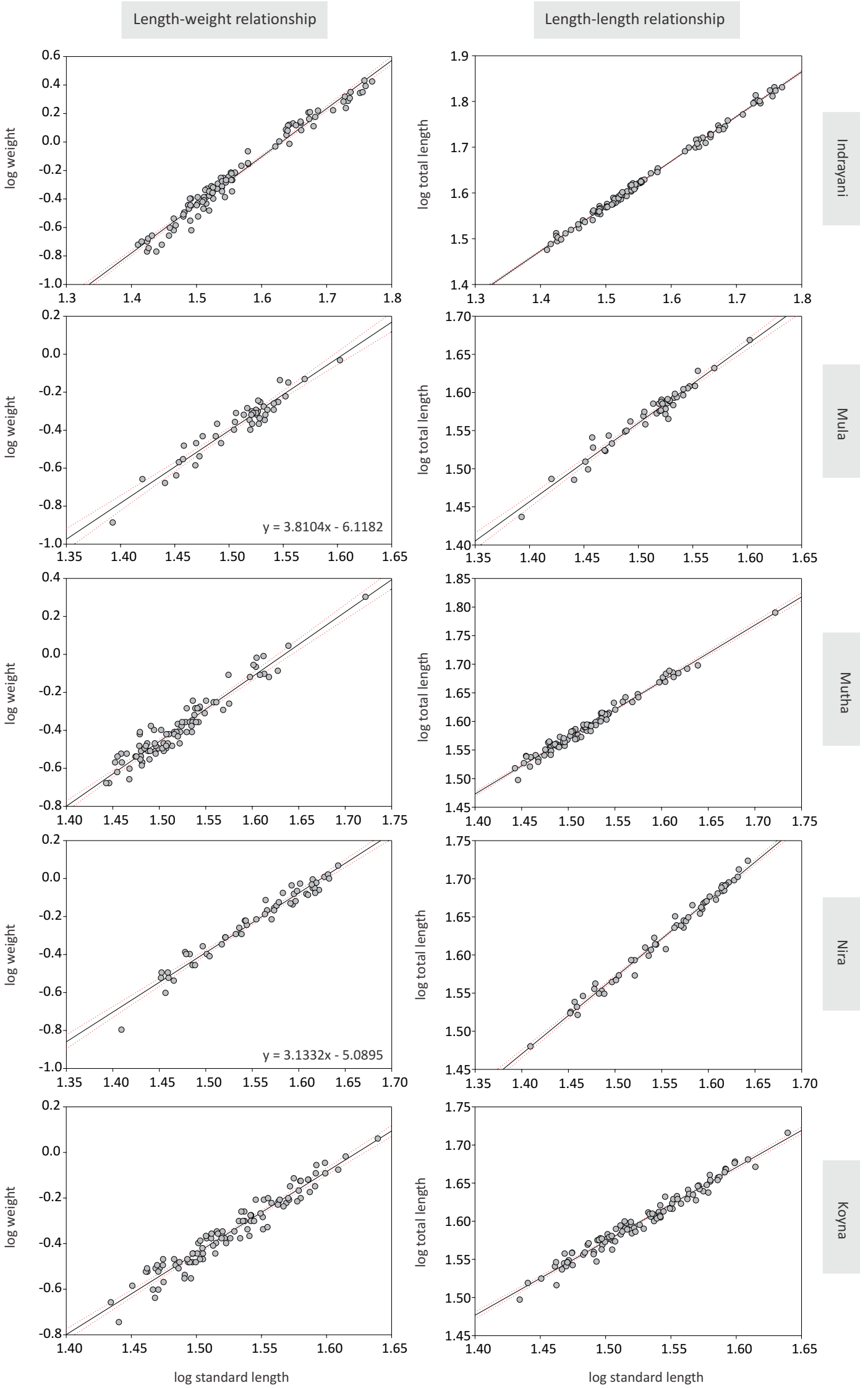

Appendix B. Scatter plots for Lepidocephalichthys thermalis. Dashed lines are $95 \%$ confidence intervals for the regression line. 

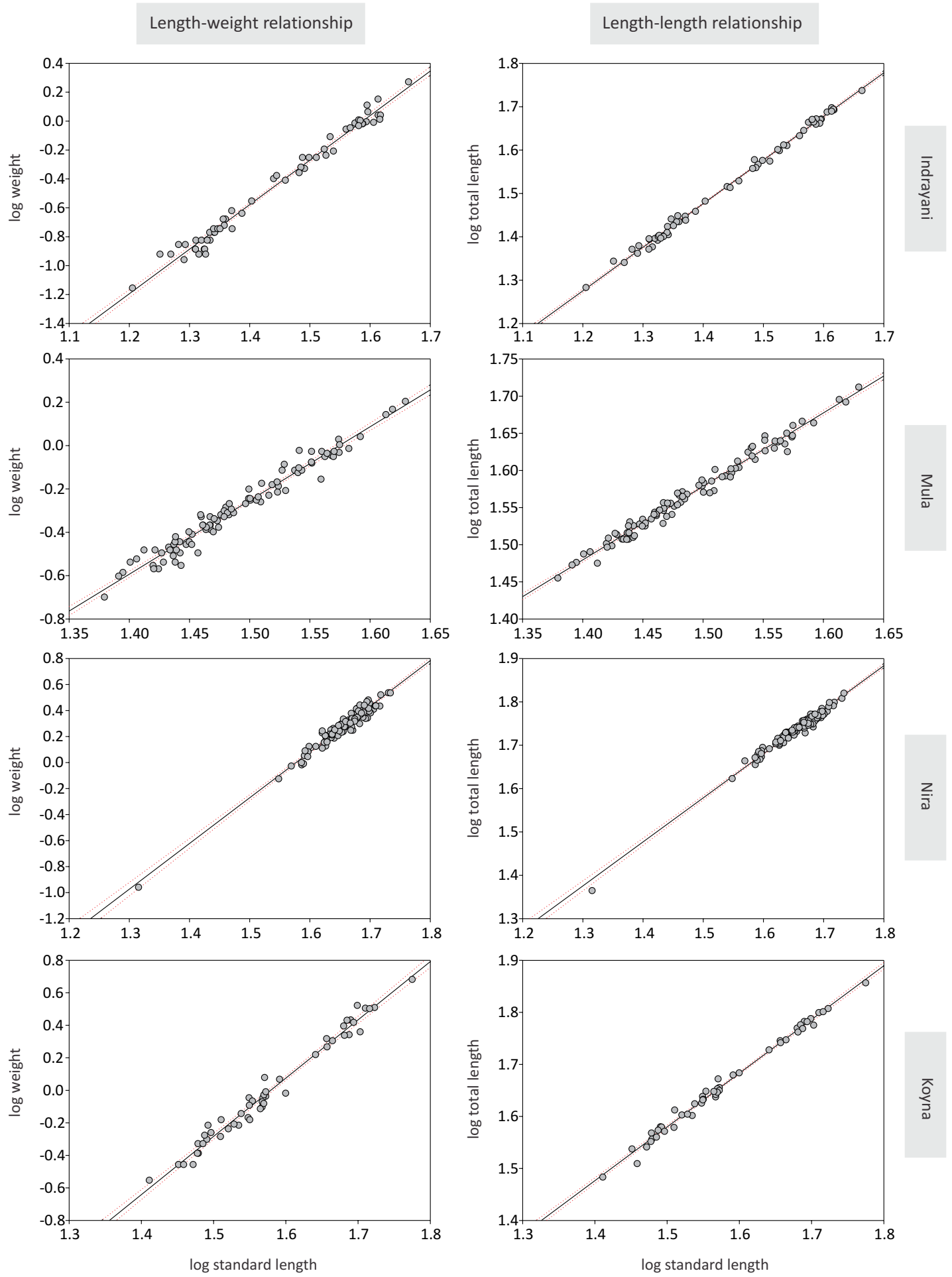

Appendix C. Scatter plots for Paracanthocobitis mooreh. Dashed lines are 95\% confidence intervals for the regression line. 

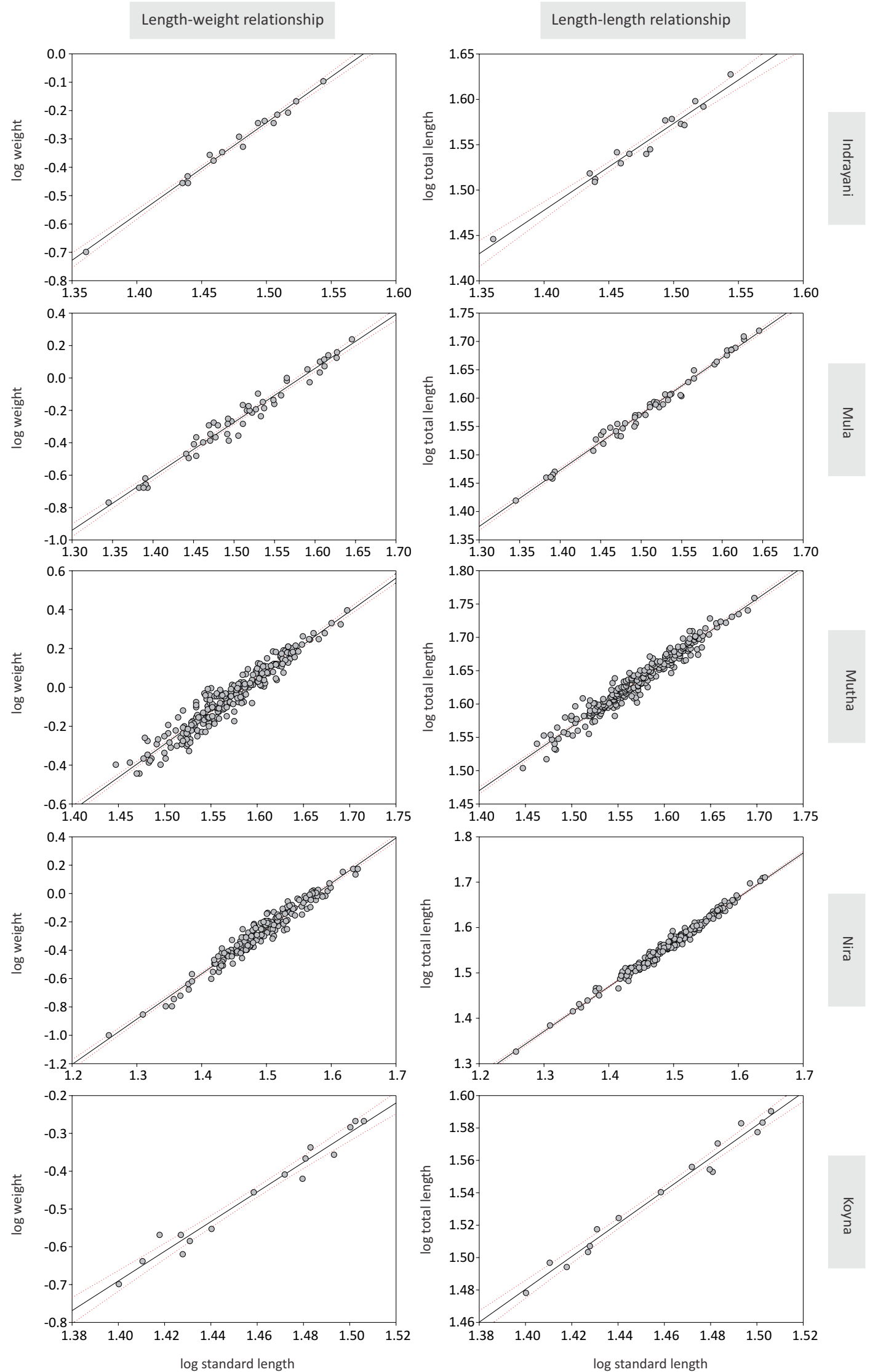

Appendix D. Scatter plots for Indoreonectes evezardi. Dashed lines are 95\% confidence intervals for the regression line. 

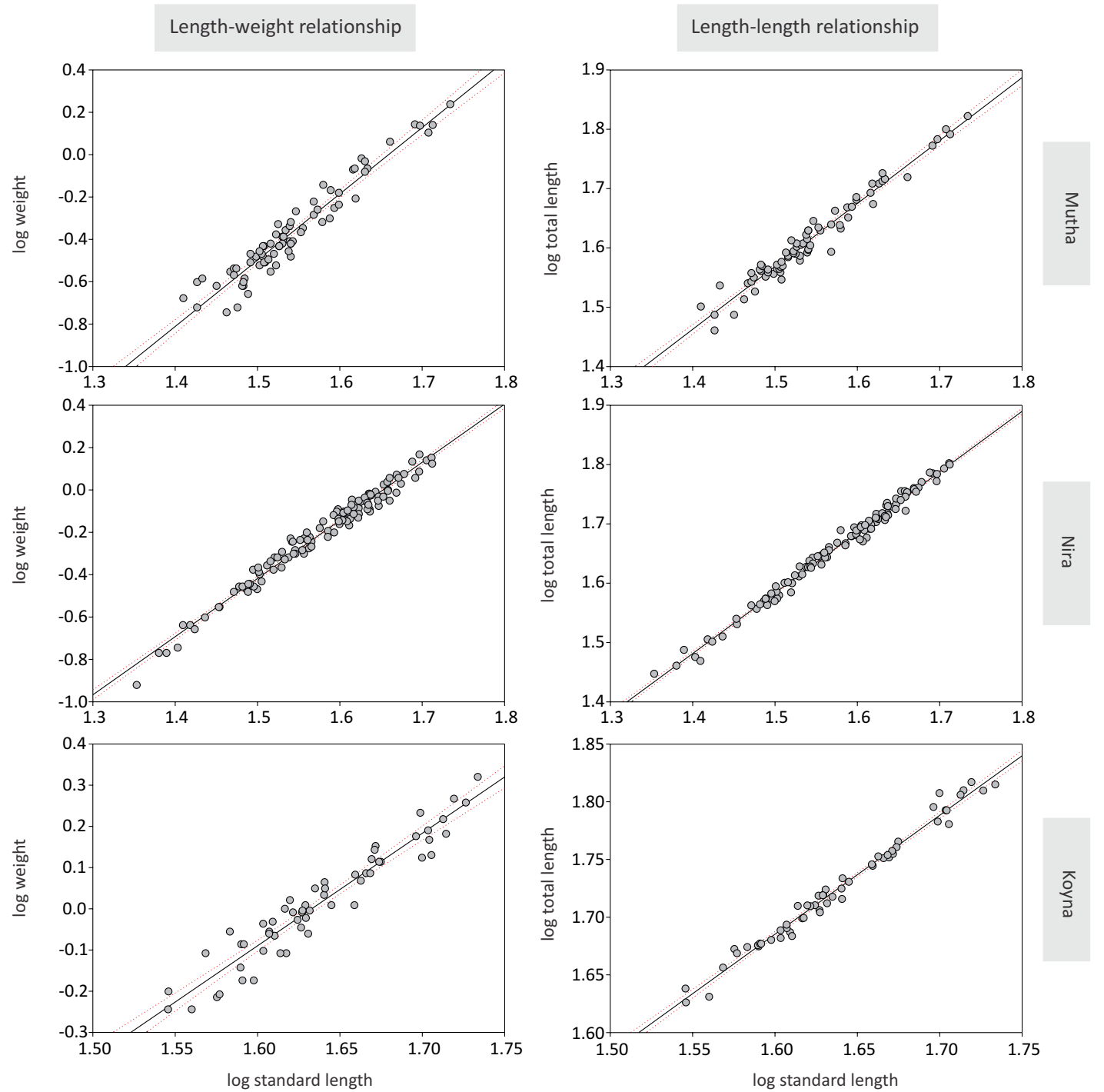

Appendix E. Scatter plots for Nemacheilus anguilla. Dashed lines are $95 \%$ confidence intervals for the regression line. 

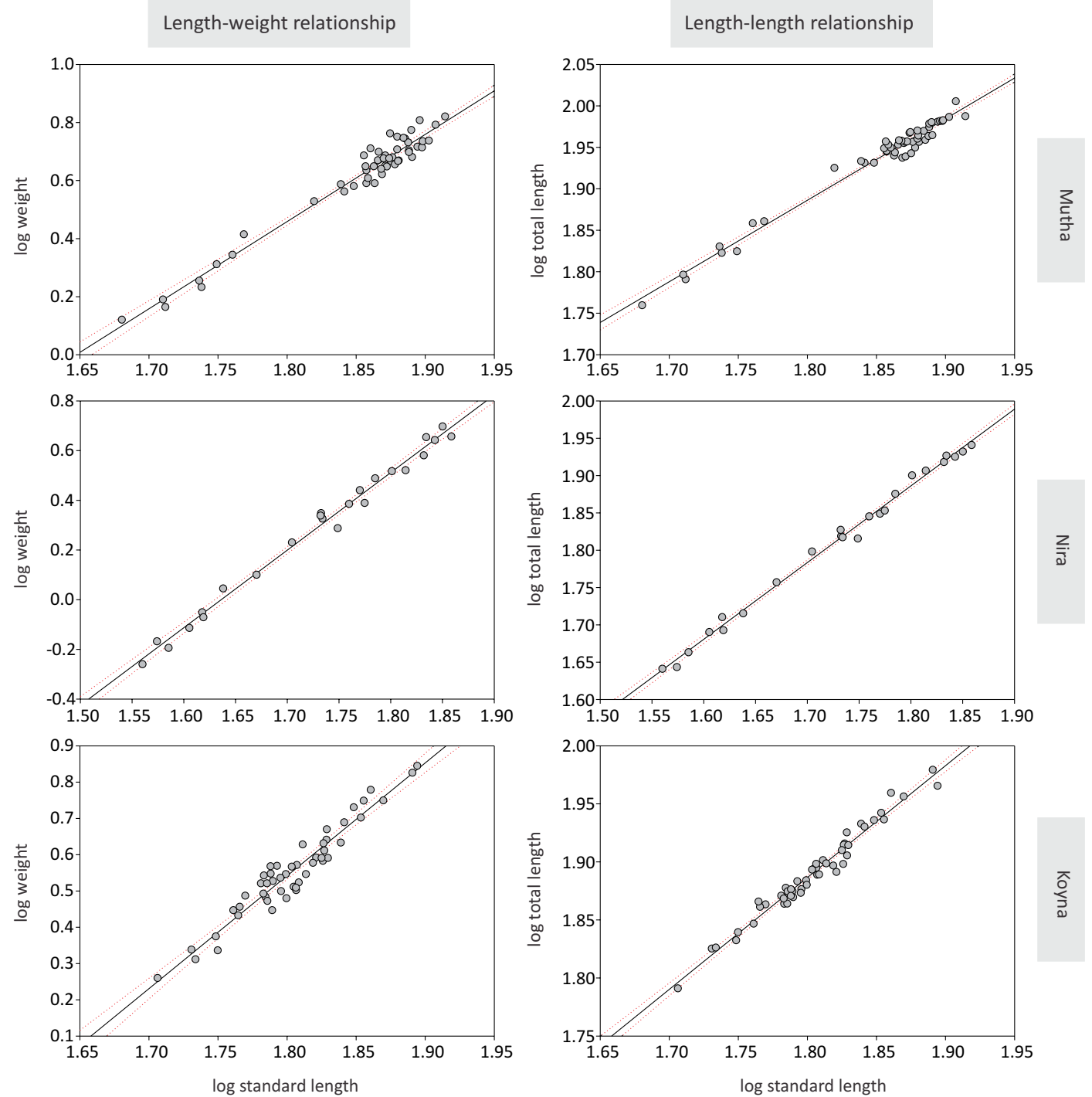

Appendix F. Scatter plots for Nemachilichthys rueppelli. Dashed lines are $95 \%$ confidence intervals for the regression line. 

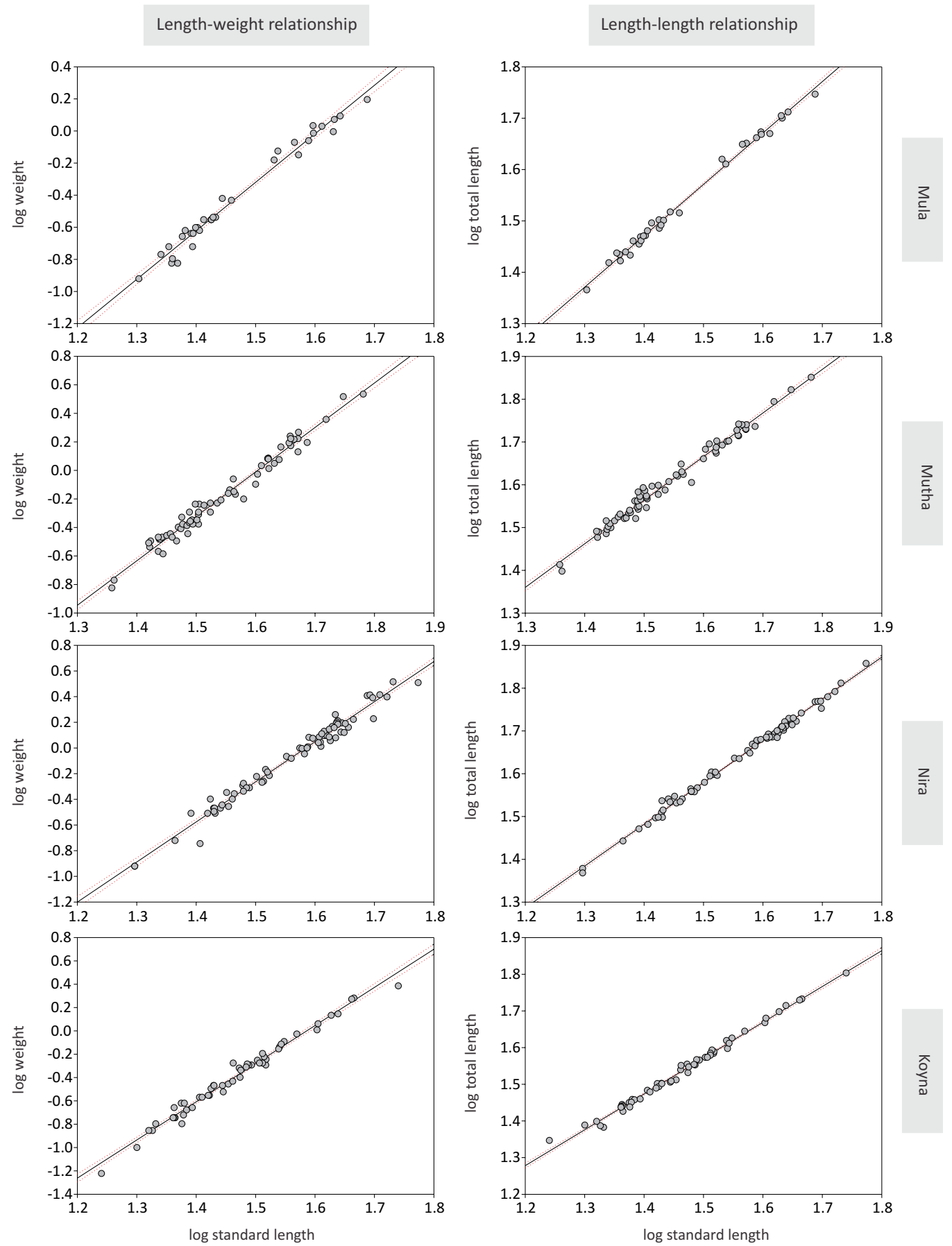

Appendix G. Scatter plots for Schistura denisoni. Dashed lines are 95\% confidence intervals for the regression line.

(2013b). Balitora jalpalli, a new species of stone loach (Teleostei: Cypriniformes: Balitoridae) from Silent Valley, southern Western Ghats, India. Journal of Threatened Taxa 5(5): 3921-3934; http:// dx.doi.org/10.11609/JoTT.03277.3921-34.

Raj, B.S. (1916). Notes on a collection of fish of Madras. Records of the Indian Museum 12(6): 249-294.

Talwar, P. K. \& A.G. Jhingran (1991). Inland Fishes of India and Adjacent Countries - Vol. I. Oxford \& IBH Publishing Co. Pvt. Ltd, New Delhi, 541pp.

Türkmen, M., O. Erdoan, H. Hallolu \& A. Yildirim (2001). Age, growth and reproduction of Acanthalburnus microlepis, Filippi, 1863 from the Yagan Region of the Aras River, Turkey. Turkish Journal of Zoology 25: 127-133.

Winfield, I.J., C.E Adams, J.D Armstrong, R. Gardiner, A. Kirika, J. Montgomery, B.M. Spears, D.C. Stewart, J.E. Thorpe \& W. Wilson (2012). Changes in the fish community of Loch Leven: untangling anthropogenic pressures. Hydrobiologia 681(1): 73-84; http:// dx.doi.org/10.1007/s10750-011-0925-8

Zar, J.H. (1999). Biostatistical analysis. Fourth edition. Pearson Education, India, 662pp. 